\title{
O USO DE DOCUMENTOS INIDÔNEOS PARA FINS TRIBUTÁRIOS E A APLICAÇÃO DA TEORIA DA CEGUEIRA DELIBERADA
}

\section{FAKE DOCUMENTS USE FOR TAX CREDITS TRANSACTIONS AND WILLFUL BLINDNESS DOCTRINE IMPOSITION}

\author{
Lauro Ericksen \\ Tribunal Regional do Trabalho - 21ª Região - TRT21 - (Natal, RN, Brasil) \\ Natalia Cristine Cavalcanti de Oliveira \\ Centro Universitário do Rio Grande do Norte - UNI-RN - (Natal, RN, Brasil)
}

Recebimento: 12 jul. 2018

Aceitação: 30 out. 2018

\begin{abstract}
Como citar este artigo / How to cite this article (informe a data atual de acesso / inform the current date of access):
ERICKSEN, Lauro; OLIVEIRA, Natalia Cristine Cavalcanti de. O uso de documentos inidôneos para fins tributários e a aplicação da teoria da cegueira deliberada. Revista da Faculdade de Direito UFPR, Curitiba, PR, Brasil, v. 63, n. 3, p. 163-188, set./dez. 2018. ISSN 2236-7284. Disponível em: <https://revistas.ufpr.br/direito/article/view/60487>. Acesso em: 22 dez. 2018. DOI: http://dx.doi.org/10.5380/rfdufpr.v63i3.60487.
\end{abstract}

\section{RESUMO}

Este artigo tematiza a questão tributária do aproveitamento de créditos de ICMS advindos de documentos declarados ideologicamente falsos. Metodologicamente, a partir do referencial teórico dos princípios constitucionais e legais, busca analisar como é possível aplicar a teoria da cegueira deliberada à restrição de aproveitamento creditício quando há documentos inidôneos. Resulta que é possível a aplicação da cegueira deliberada quando a alegação de demonstração de veracidade do contribuinte se lastrear apenas em premissas de boa-fé subjetiva. Conclui-se que a declaração de inidoneidade pode ser ilidida apenas por demonstrações inequívocas de que o tributo foi verdadeiramente recolhido, havendo o aproveitamento pelos adquirentes subsequentes, tudo isso sopesado pela ótica da teoria da cegueira deliberada. Ademais, há de se denotar que é passível de punição por meio de multas para o resguardo de conteúdos éticos mínimos procedimentalmente aplicáveis.

\section{PALAVRAS-CHAVE}

Boa-fé. Direito Tributário. Documentos falsos. ICMS. Teoria da cegueira deliberada.

\begin{abstract}
This paper discusses the tax law question about fake documents and its following credits (ICMS IVA Brazilian taxation). Methodologically, it starts from constitutional and legal principles and seeks to analyze how the willful blindness doctrine may be applied in the credit and fake documents context. It results that this theory can be applied when the tax payer declaration is anchored in its own subjective good-faith intention, without any truth demonstration at all. It concludes that fake declarations can be disrupted only by no-doubtful tax payment proofs in economic circulatory chain. In addition, the mere subjective good faith, filtered by willful blindness doctrine may suffer punitive sanctions, such as fines, protecting minimal ethical contents of tax law systems.
\end{abstract}




\section{KEYWORDS}

Good faith. Tax Law. Fake documents. IVA. Willful blindness doctrine.

\section{INTRODUÇÃO}

Há sempre nos processos administrativos de cobranças de tributos uma questão ínsita à veracidade de documentos que lastreiam o lançamento dos tributos. Essa questão também envolve os limites éticos do uso de documentos eivados de imprecisões ou impropriedades formais que os tornem inválidos. Diante dessas possibilidades de adulteração de documentos fiscais, deve-se perguntar até onde vai a boa-fé do contribuinte que deles se vale para o aproveitamento de créditos, quando se trata de impostos não-cumulativos, como o é o ICMS. Nesse compasso, surgem questões diversas: de ordem tributária, de natureza principiológica constitucional, e, em última instância, questões de fundo ético.

O princípio constitucional da não-cumulatividade é uma das proteções aos contribuintes mais relevantes insculpida na ordem constitucional brasileira, ele garante que não haja uma sobrecarga tributária ao contribuinte. Tal princípio, no entanto, não é absoluto, e sua aplicabilidade depende de certos elementos formais para que se efetive. Uma das grandes celeumas tributárias atuais consiste na aplicabilidade desse princípio em face de situações em que se atestam documentos ideologicamente falsos nas operações de crédito precedentes, ou seja, quando o contribuinte confia nas operações previamente realizadas pelos seus fornecedores e calcula o valor a ser pago de seu tributo levando em conta o mencionado princípio.

O tema a ser discutido diz respeito ao seguinte contexto: até que ponto é possível aproveitar os créditos tributários devidos a título de ICMS (imposto sobre circulação de mercadorias e prestação de serviços) quando eles se baseiam na boa-fé do adquirente. Dito de outra maneira, quais os limites da ética e do Direito para que o adquirente se apresente como imbuído de boa-fé (objetiva, ressaltese) e seja apto a aproveitar o crédito dos impostos pagos anteriormente na circulação de mercadorias e/ou serviços, dentro de sua cadeia produtiva. O problema a ser debatido transita justamente nos limites principiológicos da boa-fé e da não-cumulatividade, ou seja, imiscui nessa contextualização princípios de ordem civilista e tributária, tendo como norteamento o proceder ético do contribuinte.

A questão, no entanto, é complexa, sendo necessário levantar a seguinte hipótese de trabalho: é possível que o contribuinte, em sua suposta boa-fé, valha-se de uma “cegueira deliberada” em prol de uma defesa da não-cumulatividade tributária, para que possa, a partir de então, aproveitar-se de créditos constituídos previamente. A hipótese proposta é de grande valia e de grande atualidade, já 
que a teoria da cegueira deliberada vem sendo bastante utilizada para tratar de crimes contra a ordem tributária, e, de início, parece ser algo aplicável aos casos a serem levantados neste trabalho.

Para tratar metodologicamente do problema e da hipótese levantados, faz-se necessário perscrutar a teoria da cegueira deliberada e a sua possível aplicabilidade ao cenário posto da falsidade ideológica de documentos para fins de lançamentos tributários e aplicações de multas dessa natureza. Assim sendo, faz-se imprescindível adentrar na mencionada teoria, analisando seus elementos teóricos e conceituais, com o fito de compreender melhor os seus delineamentos na ordem tributária. Sem embargo, faz-se de grande relevância denotar que essa teoria, metodologicamente, encontra-se afeita, precipuamente, aos crimes de natureza tributária, possuindo ela, portanto, uma incidência histórica em tal seara do Direito (o ramo penal tributário). Sendo, nesse sentido, necessário investigar a sua aplicabilidade em um cenário eminentemente tributário, em princípio, “não criminal”, como no caso em tela, para definir se ela mantém a mesma aplicabilidade e inserção nos quadros concretos a serem mostrados.

Pormenorizando metodologicamente o embate a ser discutido, o imbróglio jurídico se encontra esposado no Acórdão n ${ }^{0}$ 21.291/16/2 a do Conselho de Contribuintes do Estado de Minas Gerais e possui espeque específico no art. 39, § 4 $4^{\circ}$, inciso II, alínea “a”, subalínea “a.3”, da Lei $n^{\circ}$ 6.763/75 (Lei Estadual de Minas Gerais), além de seus fundamentos constitucionais e legais a serem mais bem explanados no decorrer do trabalho em desenvolvimento.

Didaticamente, o trabalho divide-se e se desenvolve em três seções, além da presente introdução.

Para que a problemática seja mais bem compreendida, dada a complexidade da situação jurídica colocada em relevo, faz-se imperioso levar em conta as definições legais acerca de “declaração de falsidade ideológica” que dizem respeito a esse tema. Delinear melhor o esquadro jurídico e seu escorço legal a ser abordado facilita a compreensão didática sobre o tema e clarifica o debate em apreço.

Na presente seção serão abordadas as repercussões que o ato declaratório possui, incluindose nesse tema a questão da eficácia (ex tunc) dos seus efeitos. Na segunda seção, será discutida a questão da boa-fé do contribuinte em compasso com as determinações contidas na Súmula nº 509 do STJ, que garante o aproveitamento dos créditos desde que comprovada a veracidade do recolhimento dos impostos devidos nas operações prévias, atrelada à questão principiológica da nãocumulatividade dos tributos. Na terceira seção a questão da boa-fé será temperada e analisada novamente sob a ótica da teoria da cegueira deliberada e suas possíveis aplicações ao procedimento administrativo tributário de declaração de inidoneidade de documentos fiscais. 
O aglomerado das seções em descrição no parágrafo acima busca dar uma consistência teórico-formal ao presente trabalho, apresentando de maneira dialética suas disposições, tratando sequencialmente dos temas em apreço, utilizando-se de substratos teóricos de ampla profundidade, desde doutrinadores nacionais até mesmo o mais consubstanciado entendimento de pesquisadores internacionais. Tudo isso com o fito de fornecer uma pesquisa da mais alta qualidade.

\section{ATOS DECLARATÓRIOS DE INIDONEIDADE FISCAL: NATUREZA, EFEITOS E DECORRÊNCIAS}

Para que se possa iniciar o estudo acerca da questão da inidoneidade de documentos fiscais, é imperioso analisar qual ato administrativo assim o compreende (declara), qual a sua natureza e qual a eficácia dos efeitos daí decorrentes. É o ato de declaração de inidoneidade que impossibilita o uso de tais documentos fiscais para os fins que lhe são mais úteis para o contribuinte, qual seja, o aproveitamento dos créditos advindos da parcela já paga ao fisco a título de imposto incidente sobre a circulação de bens e/ou serviços. A partir da declaração de inidoneidade se resulta que todos os demais documentos acostados nessa mesma condição serão tidos como imprestáveis para tal fim. Mais importante ainda, a declaração, nos termos dados pela lei estadual que trata do caso e em acordo com a regulamentação dessa mesma lei, incapacitam os documentos que já foram produzidos em desacordo com as determinações normativas do fisco estadual. Essa segunda assertiva é a mais complexa e mais polêmica, pois assevera que os efeitos a serem extraídos da declaração em apreço possuem natureza ex tunc, ou seja, retroagem para incidir em situações pretéritas ao atestado pela própria declaração. Esse será, justamente, o principal foco de discussão teórica a ser empreendido na presente seção.

Nesse compasso, há de se indicar que a definição legal de documento ideologicamente falso é encontrada nos termos do art. 39, § $4^{\circ}$, inciso II, da Lei $n^{\circ} 6.763 / 75$, e suas subalíneas, que incluem as seguintes hipóteses:

[...] o documento fiscal autorizado previamente pela repartição fazendária: a.1 - que tenha sido extraviado, subtraído, cancelado ou que tenha desaparecido; a.2 - de contribuinte que tenha encerrado irregularmente sua atividade; a.3 - de contribuinte inscrito, porém sem estabelecimento, ressalvadas as hipóteses previstas em regulamento; a.4 - que contenha selo, visto ou carimbo falsos; a.5 - de contribuinte que tenha obtido inscrição estadual ou alteração cadastral com a utilização de dados falsos; a.6 - não enquadrado nas hipóteses anteriores e que contenha informações que não correspondam à real operação ou prestação; b) o documento relativo a recolhimento de imposto com autenticação falsa; [...] (MINAS GERAIS, 1975). 
Há uma importante discussão a ser considerada no presente caso - ela diz respeito ao termo “declaração” de documento ideologicamente falso. Discute-se se o termo “declaração” possui natureza "meramente declarativa”, e daí ele viria apenas a trazer a lume uma situação preexistente e que já reverberava na ordem jurídica, ou se possui alguma noção “normativa”, daí a repercutir apenas após o fato constitutivo da própria declaração. Aliomar Baleeiro (1991, p. 503) assevera que a declaração contida no ato declaratório não altera a situação ali descrita, não cria, não extingue ou modifica direitos ou deveres. Por mais redundante que pareça, o ato declaratório é apenas um ato administrativo, que só declara, reconhecendo um direito (ou um vício, no caso em apreço) já existente, sem nada acrescentar à natureza ou aos efeitos daquele (AKSELRAD, 1999, p. 400-429). Ou seja, de forma repetitiva e analítica, pode-se asseverar de modo absoluto que não há nada de diverso na declaração que seja preexistente à própria declaração; sem uma tautologia pré-estabelecida (VIEGAS, 1999, p. 182) ${ }^{1}$ na construção declaratória decorrem que não há declaração e que não há efeitos $e x$ tunc, daí a reiteração do fato pretérito ser sempre algo já dito e constituído e que por si só já opera seus efeitos desde então por já ser “perfeito”, já ter percorrido todos os passos ou etapas para a sua conclusão plena e efetiva no passado.

Inobstante, a declaração de falsidade ideológica contida em um documento não sana o vício nele contido nas situações que porventura ocorreram entre a constituição falsa do documento e a sua declaração. Nesse ínterim o documento não era idôneo e o deixou de ser por causa da declaração. Dessa forma, não há nenhuma constituição fática com a declaração, ou a partir do ato declaratório (COÊLHO, 2007, p. 649). Se não se cria precipuamente a situação em que a falsidade é a ele atribuída, seus efeitos devem reverberar desde então, ainda que o reconhecimento de tal vicissitude seja depreendido a posteriori, ou seja, após a decorrência do próprio fato declarado efetivamente ter ocorrido.

Por mais filosófico que possa soar, o ato declarativo é o "reconhecimento da existência” de um fato pretérito (BORGES, 1999, p. 421). Nesse sentido, se se trata apenas de uma rememoração de algo já prevalente, a declaração nele contida deve ser reconhecida de forma que remeta ao início constitutivo do ato, prévio à própria declaração. Tal conceituação leva ao entendimento de que os atos declaratórios possuem natureza ex tunc, retroagindo ao momento da constituição, sem haver nenhuma inovação prévia na formalização fática do ato que possui sua eficácia ex tunc (WICHARY, 2010, p. 115). Assim, o ato simplesmente não reverbera apenas para adiante do reconhecimento da

\footnotetext{
${ }^{1}$ Toda tautologia relevante para a construção do efeito ex tunc está filosófica e juridicamente calcada na análise do status quo ante da análise que defere o efeito em tela; sem essa espécie de retroação temporal a análise pretendida nem sequer é possível de ser operada.
} 
existência do ato eivado de vício jurídico (qual seja, a falsidade ideológica de documentos). Ao se falar de natureza ex tunc, remete-se à ação verbal de “declarar” (FRUMAROVÁ, 2015, p. 79); desse modo, ao se falar em declaração sempre se faz menção a um fato pretérito que desde a sua constituição “existencialmente fática” já reverbera na ordem jurídica, sem que seja necessário nenhum ato posterior a lhe conceder possibilidade de fruir naturalmente por si mesmo.

Em síntese, há de se compreender que todo ato declaratório em sede de procedimento administrativo tributário, não apenas os que reconhecem direitos dos contribuintes, mas, também, os que denotam vícios formais, possui efeitos que recuam até a data do ato (VICENTE, 2016, p. 278). O mencionado retorno à origem factual do ato denota a sua formalização, podendo-se, a partir de então, aferir sua correta constituição formal em um momento posterior.

Por mais que seja de grande relevância acadêmica discutir a natureza do ato declaratório e seus efeitos, na prática procedimental tributária do caso posto em relevo na introdução do trabalho em andamento existe um argumento pragmático bastante singelo, mas de grandiloquência resolutiva. Conforme disposição expressa contida no artigo 134-A do Regulamento do ICMS de 2002 do Estado de Minas Gerais (RICMS/2002, doravante), o ato declaratório de falsidade ideológica é passível de impugnação (tecnicamente, passível de recurso). Nesse ponto, o ato declaratório expõe o substrato fático de diligências que conduzem à conclusão sobre a configuração formal da irregularidade aferida. Busca-se, portanto, atestar cabalmente com esse ato declaratório que os documentos fiscais estão eivados de irregularidades e de vícios que impossibilitam aproveitar os créditos neles descritos.

De toda a forma, o mencionado artigo do RICMS/2002, em respeito aos princípios do contraditório e da ampla defesa insculpidos na ordem constitucional (artigo 5º inciso LV, da Constituição Federal) (BRASIL, 2017), garante ao contribuinte o prazo de 10 dias para apresentar recurso ao ato declaratório em relevo. Dessa maneira, ele pode produzir as provas que almejar para tentar argumentar em prol da não falsidade ideológica do documento, e, consequentemente, no sentido da sua aceitação como documento fiscal hábil a aproveitar os créditos tributários lá descritos como pagos nas operações anteriores.

Consequentemente ao delineamento do procedimento tributário em apreço, há de se considerar que não recorrer, ou, melhor dizendo, deixar transcorrer in albis o prazo recursal, e depois arguir a possibilidade de uma declaração de efeitos ex nunc para o ato declaratório não parece ser uma das possíveis atitudes mais corretas a ser tomada pelo contribuinte, algo que desde já abre a discussão acerca da boa-fé do contribuinte nos casos que envolvem a declaração de documento ideologicamente falso para fins de aproveitamento de créditos tributários nas circulações de bens e/ou serviços. Nesse gancho, o estudo mais aprofundado da Súmula nº 509 do Superior Tribunal de Justiça 
(BRASIL, 2014) versa diretamente sobre a questão da boa-fé, e, em segundo plano, sobre o princípio da não-cumulatividade, os dois próximos temas a serem debatidos no trabalho em andamento.

\section{BOA-FÉ (OBJETIVA), DEMONSTRAÇÃO (DE VERACIDADE) E A NÃO- CUMULATIVIDADE TRIBUTÁRIA}

Na seção em desenvolvimento se faz premente retomar a discussão encetada no último parágrafo da seção precedente e adentrar no entendimento sumulado pelo STJ atinente ao procedimento a ser adotado quando o crédito tributário for advindo de documentos fiscais declarados inidôneos. É necessário destacar que existem dois princípios abordados na súmula em questão, um deles de ordem legal (infraconstitucional), debatido de forma explícita na redação do teor sumulado, e outro de natureza constitucional, posto de forma implícita na assertiva sumular.

O primeiro princípio é o da boa-fé, princípio civilista que será abordado inicialmente, logo após a revisão textual da súmula. O segundo princípio é o da não-cumulatividade, o qual, por estar insculpido no próprio texto constitucional, possui essa natureza pétrea (pode ser considerado um direito individual propriamente dito), e, em sede tributária, possui uma conexão bastante estreita com o supramencionado princípio da boa-fé, o qual é citado textualmente. A análise conjugada desses dois princípios e da súmula em apreço se faz indispensável para que a contextualização dos documentos declarados ideologicamente falsos pela autoridade fiscal seja mais bem compreendida, e para que a excepcionalidade da aceitação de tais documentos seja posta em relevo na discussão que se segue.

Dando prosseguimento ao debate, é de grande importância observar que a Súmula nº 509 do STJ enuncia que: "É lícito ao comerciante de boa-fé aproveitar os créditos de ICMS decorrentes de nota fiscal posteriormente declarada inidônea, quando demonstrada a veracidade da compra e venda" (BRASIL, 2014). Em uma leitura primeira da súmula em espeque já é possível assimilar que a boafé não é algo presumido pelo fisco, ou seja, não é algo que se apresenta de plano para fins tributários sem que seja necessário o contribuinte ter nenhuma ação ou atitude nesse sentido. Ao contrário, o verbo de que a súmula em apreço se utiliza é “demonstrar”; assim, faz-se imperioso que o contribuinte seja capaz de “demonstrar uma verdade”, qual seja ela, que o tributo foi efetivamente recolhido na operação de compra e venda que o antecede na cadeia produtiva, para que o crédito que lhe é concedido seja aproveitado na operação subsequente.

Por demonstração de verdade, tomando um referencial de estudo da filosofia analítica, devese tomar por base o entendimento de Alfred Tarski (2007, p. 203), segundo o qual: 
Uma demonstração formal de uma sentença dada consiste em construir uma sequência finita de sentenças tal que (1) a primeira sentença na sequência é um axioma, (2) cada uma das sentenças seguintes ou é um axioma ou, então, é derivável diretamente de algumas sentenças que a precedem na sequência através de uma das regras de demonstração, e (3) a última sentença na sequência é aquela que deve ser demonstrada.

Diante do exposto, percebe-se que é necessário um encadeamento lógico entre fatos assertivos que almejem provar a veracidade de um recolhimento com base em um documento ideologicamente declarado falso pela autoridade fiscal competente. Toda demonstração, e a demonstração para fins de veracidade de operações de crédito tributário não foge à regra, depende das conexões lógicas existentes entre axiomas²; seguramente, cada um desses axiomas deve expor uma premissa considerada necessariamente verdadeira para que a próxima proposição na cadeia lógica seja aceita como decorrente das próprias regras de demonstração estabelecidas sistematicamente e atinente a elas. Ou seja, tratando-se de uma verdade demonstrada, seguindo as premissas de Tarski, não há de se falar em verdade presuntiva, qualquer que seja a alegação probatória a ser trazida a lume.

Faz-se imperioso que a narrativa empregada tenha finitos termos e indicações sequenciais entre si, para que as derivações lógicas ou factuais sejam interconectadas reciprocamente. Com essas regras de demonstração, garante-se de modo inescusável e inarredável que o fato a ser provado é verdadeiro, e que, portanto, não pairam dúvidas acerca de sua aceitabilidade para o sistema tributário como algo indispensável, como o recolhimento correto do tributo na operação de compra e venda precedente ao aproveitamento do crédito.

Essa, certamente, é a explicação mais simples e mais aparente que pode ser dada em uma primeira leitura da Súmula $\mathrm{n}^{0}$ 509. Todavia, o tema não é nada complicado, e sua alegada complexidade advém, precipuamente, do que é a boa-fé mencionada e como ela pode (se é que pode) ser aferida quando há inidoneidade no documento fiscal em que ela se funda para garantir a existência do crédito tributário em destaque. Ainda que não seja o intento primordial do trabalho em andamento teorizar sobre conceitos civilistas atinentes aos seus princípios fundamentais, afigura-se necessário tecer algumas considerações acerca da boa-fé e como ela se relaciona com a questão da declaração de falsidade ideológica de documentos fiscais, ponto nevrálgico do trabalho.

É lição comezinha advinda do direito civil que a boa-fé é um instituto que se subdivide em boa-fé objetiva e boa-fé subjetiva. Em termos bastante simplórios, a boa-fé objetiva é aquela que se

\footnotetext{
${ }^{2}$ A explanação da teoria de Tarski da verdade por demonstração serve como critério filosófico-crítico que lastreia o entendimento defendido no presente artigo. Não se dispõe, portanto, a se analisar dogmaticamente como esse entendimento se espraia em outros excertos jurisprudenciais, já que o escopo por ora desenvolvido se torna perfeito e bastante para o caso concreto, que é o cerne do artigo.
} 
verifica factualmente, independente da intenção do agente, ao passo que a boa-fé subjetiva é aquela que é aferida pela intenção do agente em uma prática inclinada ao bem e ao bom resultado (finalístico) do seu âmago intimamente considerado (VENOSA, 2014, p. 359). Convém enunciar também que a boa-fé é algo que varia seu sentido em função do contexto legal (seara penal ou seara civil, por exemplo), e também em função de outras ferramentas versáteis da dinâmica jurídica, como, por exemplo, razoabilidade ou dever (BUELL 2011, p. 645). Em termos práticos a modalidade de boa-fé que deverá servir como parâmetro de interpretação e de análise para os casos de declaração de inidoneidade de documentos fiscais é a objetiva, haja vista que a sua forma subjetiva ${ }^{3}$ é algo raramente utilizada na seara jurídica, em virtude de ser (praticamente) impossível determinar a intenção do agente e suas possíveis reservas mentais em tais atos de cumprimento ou descumprimento de obrigações civis.

O cerne interpretativo do princípio da boa-fé no direito brasileiro advém do artigo (ou seção) 242 do Bürgerliches Gesetzbuch (BGB - Código Civil Alemão), o qual enuncia, textualmente, que: “Der Schuldner ist verpflichtet, die Leistung so zu bewirken, wie Treu und Glauben mit Rücksicht auf die Verkehrssitte es erfordern” (SCHNORR, 2004, p. 181). Em uma tradução livre: “o devedor tem o dever de cumprir a avença de acordo com os pressupostos de boa-fé, levando os costumes em consideração”. O excerto em apreço é de grande valia para a presente abordagem por impor um dever ao devedor, qual seja, o de se comportar e agir de acordo com os preceitos da boa-fé (objetiva, ressalte-se), no cumprimento de sua obrigação, sem arguir ou apresentar subterfúgios a essa forma de se comportar no seu mister de cumpridor de suas obrigações.

Denota-se, portanto, que o contribuinte deve se portar de acordo com os costumes estatuídos e segundo as determinações normativas que posicionem juridicamente o que é a boa-fé no cumprimento das obrigações (tributárias), para que proceda de modo justo e bom eticamente falando (WIELING, 2006, p. 373), com o intento de que seu comportamento seja espelhado e reproduzido pela parte contrária. Semelhantemente, a colocação da boa-fé como um dever da parte que está em contraposição ao fisco corrobora com a ideia ínsita na Súmula nº 509, em que se exige a demonstração da veracidade do recolhimento do tributo para que a boa-fé seja levada em consideração.

A boa-fé, portanto, configura-se como um verdadeiro padrão mínimo de expectativa na conduta ética do contribuinte; representando um verdadeiro estandarte básico de comportamento, a

\footnotetext{
${ }^{3}$ Pode-se adiantar que as reservas mentais usualmente atreladas à boa-fé subjetiva configuram o que mais adiante se tratará por "cegueira deliberada” (willful blindness). Nesse passo, há uma linha bastante tênue entre a demonstração efetiva de veracidade da boa-fé objetiva e a cegueira deliberada como modo de estado mental atrelado a um comportamento ilusivo de boa-fé subjetiva.
} 
boa-fé atua classicamente como norma comportamental, concorrendo para determinar a conduta devida pelos sujeitos envolvidos numa relação (RIBEIRO, 2005, p. 6). Ela é uma atuação com lealdade, que respeita interesses legítimos (e obriga o respeito refletido de tais interesses), sem abuso e também sem ocasionar lesão ou causar desvantagem à outra parte (MARQUES, 2004, p. 181). Sinteticamente, a "boa-fé objetiva é um standard de comportamento leal com base na confiança, [...] respeitando as expectativas legítimas e contribuindo para a segurança” (MARQUES, 2000, p. 87). Ou seja, é uma conduta operada por pelo menos uma das partes (mas desejável em ambas) que gera a expectativa de reciprocidade no tratamento ético e cortes no desenrolar da relação encetada.

Desse modo, ambas as partes na relação descrita devem cooperar para que a obrigação tributária encetada alcance um bom fim, isto é, o cumprimento a contento das obrigações estabelecidas, com o devido lançamento do tributo, com o seu devido pagamento a cada operação, e havendo crédito a ser compensado por operação pretérita, que tais valores sejam descontados do contribuinte a seguir na cadeia produtiva, sem que ele arque, indevidamente, com os valores pagos efetivamente pelo fornecedor anterior ou a quem o precedeu. A boa-fé, no sentido proposto, segue a lógica de uma conduta espelhada, que deve ser refletida pela parte a quem inicialmente dela se aproveita, retribuindo-a de igual maneira a quem devida e corretamente se comporta no curso do cumprimento de suas obrigações (tributárias). Não sendo, portanto, detentor de um tratamento de boa-fé quem não age imbuído de tal axioma valorativo de comportamento em sua lida obrigacional.

Tal como indica Edwin van der Bruggen (2003, p. 26), qualquer interpretação ou proposição hermenêutica que se atenha ao sentido mais profícuo de boa-fé (objetiva) não pode trespassar ou ultrapassar os limites textuais de sua aplicabilidade. Ou seja, a boa-fé em proveito do contribuinte não pode afetá-lo de um modo que lhe seja retirada uma conduta exigível como normal ou ordinária no curso do cumprimento de suas obrigações tributárias. Assim, por mais que se intente rechaçar a possibilidade de uma dupla tributação (ou a repetitividade cumulativa do pagamento de um imposto devido, mas, já pago, ainda que parcialmente, como é o caso do ICMS em discussão), ao alvedrio da boa-fé objetiva, ela não pode servir de uma escusa no cumprimento das determinações do fisco em prol de uma organização contábil-fiscal, tampouco pode servir como escusa no cumprimento da obrigação (principal) por si mesma. Dessa maneira, por mais que ela seja um "direito” calcado em um princípio benéfico ao contribuinte, a (indicação interpretativa de sentido da) boa-fé contém, em si mesma, certas formalizações de demonstração e de veracidade que acompanham o cumprimento ordinário das próprias obrigações tributárias, como já alude o previamente citado artigo do BGB.

Além da noção privatista acima abordada, há de se fazer o cruzamento desse entendimento com a dimensão pública e tributária que envolve o cerne do trabalho em desenvolvimento. Ao se 
mencionar o princípio da boa-fé no campo público, necessariamente, há de se atrelá-lo ao conceito mais comezinho de Estado Democrático de Direito. Tal ponto se relaciona com a possibilidade (ou melhor, a necessidade urgente e premente) de se poder antecipar e antever as tomadas de decisão do Estado perante o cidadão, e de forma mais específica, no seu trato com o contribuinte (ou qualquer que seja a relação tributária encetada com o sujeito de direito). Dessa maneira, como asseveram Sacha Calmon Navarro Coêlho e Valter Lobato (2005, p. 111), pugna-se no Estado de Direito que haja “boafé no trato dos cidadãos-contribuintes de forma segura (previsível, certa, limitada) e justa (porque certa, previsível, limitada)”. Outrossim, há de se observar que o valor da segurança jurídica encontrase agregado a essa noção de boa-fé sob a égide publicista, pois ele também uma consequência e uma premissa do Estado de Direito.

Assim, a boa-fé no âmbito tributário, como um derivado da segurança jurídica, deve ser considerada um avanço especial na formação do Estado Democrático de Direito, protegendo o indivíduo (cidadão e contribuinte) de atos arbitrários do Poder Público, já que as intervenções estatais podem ser muito contundentes e, por vezes, até mesmo injustas (TORRES, 2018, p. 207). Ter certeza da aplicação dos limites legais, bem como poder antever as consequências dessa aplicação, é o que caracteriza e delineia os parâmetros jurídicos do princípio da boa-fé na seara tributária. Isso acaba por trazer confiança, tranquilidade e certeza no que tange à tributação, por parte dos governados, assegurando-se, assim, o respeito para com o governo e também um sentimento de compartilhamento com a responsabilidade da política tributária organizada e operada democraticamente.

Impende destacar que o princípio da boa-fé, na seara por ora abordada, também se relaciona intrinsecamente com o denominado, por Humberto Bergmann Ávila (2016, p. 360), “princípio da proteção da confiança”. Esse princípio serve:

[...] de instrumento de defesa de interesses individuais nos casos em que o particular, não sendo. Protegido pelo direito adquirido ou pelo ato jurídico perfeito, em qualquer âmbito, inclusive no tributário, exerce a sua liberdade, em maior ou menor medida, confiando na validade (ou na aparência de validade) de um conhecido ato normativo geral ou individual e, posteriormente, tem a sua confiança frustrada pela descontinuidade da sua vigência ou dos seus efeitos, quer por simples mudança, quer por revogação ou anulação, quer, ainda, por declaração de sua invalidade. Por isso, o princípio da proteção da confiança envolve, para a sua configuração, a existência de (a) uma base da confiança, de (b) uma confiança nessa base, do (c) exercício da referida confiança na base que a gerou e da (d) sua frustração por ato posterior e contraditório do Poder Público.

Percebe-se, portanto, que o princípio da boa-fé é a raiz individual da proteção da confiança e se manifesta na ideia de que a confiança pressupõe uma relação pessoal forjada de um modo determinado (LUENGO, 2002, p. 150). A proteção da confiança faz gerar de maneira prévia ao início dos eventos procedimentais um elo de reciprocidade na consecução dos fins tributários tanto no 
sujeito ativo quanto no passivo dessa relação. Assim, deposita-se na certeza e na previsibilidade dos atos administrativos tributários que venham a ser cumpridos, seguindo as premissas básicas da boafé e na confiança que tais atos não ensejarão medidas punitivas ou injustas do Poder Público na consecução de sua atividade primária e seguindo também o interesse público como fim último de tal atividade.

Definitivamente, pode-se compreender, como assevera Gabriel de J. Tedesco Wedy (2007, p. 260) que: “a boa-fé está no âmago do procedimento administrativo e não pode ser desvinculada do mesmo. Se não for observada estritamente a boa-fé, o procedimento administrativo é ilegal”. A não observância desse princípio basilar gera inúmeras consequências gravosas diretamente para o cidadão, tais como injustiças na base de cálculo tributário, aplicação de multas e outros efeitos deletérios. Para o Poder Público, essa não observância, além de implicar a ilegalidade do procedimento, gera também desconfiança, descrédito na sua função de tributar, e, por vezes, descamba para atos de corrupção ou abuso da autoridade tributária.

Como já destacado, do princípio da boa-fé, combinado com outros princípios tributários acessórios, segue-se de maneira que esse princípio dá azo à concatenação ao princípio da nãocumulatividade tributária. O princípio tributário em apreço se encontra no artigo 155, § $2^{\circ}$, inciso I, da Constituição Federal: "Será não-cumulativo compensando-se o que for devido em cada operação relativa à circulação de mercadorias ou prestação de serviços com o montante cobrado nas anteriores pelo mesmo ou outro Estado e pelo Distrito Federal” (BRASIL, 2017). A partir da própria definição constitucional do princípio da não-cumulatividade já se percebe que ele é aplicável ao ICMS por se tratar de um imposto que se repete ao longo do tempo em uma mesma cadeia econômico-produtiva. Ou seja, é um imposto dotado de várias etapas ou de muitas fases, e que incide em cada uma delas. A não-cumulatividade, de plano, incide para que a cada fase o valor total do imposto devido não acabe por distender seu conteúdo, protelando-se temporalmente e acumulando-se exponencialmente a cada nova operação de compra e venda. Vedar a cumulatividade do ICMS consiste, precipuamente, em rejeitar a possibilidade de uma repetição na cobrança do lançamento tributário a cada nova etapa de circulação de mercadorias, bens ou serviços no interior das cadeias produtivas do seio social.

Depreende-se, conceitualmente, que o ICMS é classificado como um imposto multifásico (ou plurifásico, o que denota, em ambos os casos, que não há apenas uma incidência isolada que o qualifique como “unifásico”), e que, caso não seja aplicado o princípio da não-cumulatividade, acaba por ocorrer o efeito cascata, ou seja, um acúmulo trófico quantitativo em cada uma de suas fases (ROSA, 1995, p. 15). Nesse mesmo sentido, é correto depreender que o objetivo da nãocumulatividade consiste em evitar acréscimos indevidos e indesejáveis de tributos que onerem de 
forma artificial e exponencialmente danosa o preço do produto (bem ou serviço) final (MELO; LIPPO, 2008, p. 146), impedindo, dessa feita, que haja a superposição de cargas tributárias que advenham da incidência de impostos dentro de um ciclo operacional, em situação de persistência temporal multifásica.

Vedar o efeito em cascata do ICMS consiste em proteger o contribuinte da bitributação ou da “multitributação”; o primeiro caso ocorre quando ele paga o imposto duas vezes, como adquirente e como vendedor do produto ou do serviço, e a “multitributação” ocorre quando, já tendo pago uma vez como adquirente ou como vendedor de uma matéria-prima, esse bem retorna já beneficiado e passa a reintegrar a cadeia produtiva do contribuinte, devendo o mesmo imposto (ICMS) ser pago mais uma vez, sem os devidos aproveitamentos de crédito tributário incidentes no caso reportado.

Ao se falar em cumulação tributária (ou melhor, em vedação à cumulação tributária segundo o princípio da não-cumulatividade) deve se compreender que esse fenômeno jurídico ocorre, precipuamente, em sede de tributos que se protraem em diversas fases ou etapas, tal como é o caso do ICMS. A reincidência tributária ocorre em virtude da própria natureza multitudinária do imposto mencionado, daí podendo se advir a questão do bis in idem ou da bitributação, já que ambos fazem menção à repetição da incidência tributária sobre uma situação ou em referência à repetição da tributação em eventos similares em sua constituição fática propriamente dita, como se verá melhor em sua conceituação a seguir.

Tecnicamente, há quem diferencie os fenômenos do bis in idem tributário e da bitributação. Este (bitributação) ocorreria quando mais de um ente (político) tributário, por exemplo, a União e o estado federativo intentam tributar uma mesma situação (uma compra e venda); já aquele (o bis in idem) ocorreria quando o mesmo ente (estado federativo, no caso do ICMS) almeja tributar uma mesma situação fática, que se repete temporalmente numa cadeia produtiva (BARREIRINHAS, 2009, p. 104). Em regra, ambas as condutas fiscais são proibidas pelo atual sistema jurídico brasileiro, a despeito das exceções à bitributação já constantes no próprio texto constitucional: artigo 154, II, da Constituição Federal (BRASIL, 2017). No que tange à bitributação, apesar de não existir nenhuma vedação expressa e genérica de sua ocorrência, a regra contida no artigo 154, I, da Constituição da República (BRASIL, 2017) restringe a possibilidade de bis in idem, porque impede a União de usar a competência para “clonar” um imposto que já se encontra na sua competência (ALEXANDRE, 2011, p. 220). Resumidamente, pode-se colocar, portanto, que a bitributação, em seu conceito, reporta-se a tributos “diversos” incidindo em uma mesma situação (fato gerador), quando, na verdade, não há diversidade em tais tributos, eles são uma mera construção teórica para um mesmo intento impositivo do Estado (ou, quiçá, uma repetida incidência do mesmo tributo sobre o mesmo fato na 
cadeia produtiva); já no bis in idem não há uma diversidade de incidência de espécies tributária sobre um mesmo fato gerador, apenas uma concorrência subjetiva estatal em seu exercício tributário.

Em síntese, o que importa destacar, para além das diferenciações conceituais de fulcro etimológico, é que o princípio da não-cumulatividade se constitui como uma barreira a impedir a prevalência da bitributação em sede de sucessão de operações na cadeia produtiva do ICMS. Esse é o escopo principal contido no cerne do mencionado princípio, e sobre ele deve se assentar o estudo a ser desenvolvido a seguir. A disposição legal afeita ao princípio da não-cumulatividade se encontra normatizada e mais bem regulamentada no artigo 19 da Lei Complementar $n^{\circ}$ 87, vulgo e doravante denominada Lei Kandir (BRASIL, 2017), o qual dispõe que:

O imposto é não-cumulativo, compensando-se o que for devido em cada operação relativa à circulação de mercadorias ou prestação de serviços de transporte interestadual e intermunicipal e de comunicação com o montante cobrado nas anteriores pelo mesmo ou por outro Estado.

A diretriz constitucional e legal da não-cumulatividade não advém de uma benesse estatal pura e simplesmente; ao contrário, a cumulatividade tributária oferece algumas desvantagens. No rol de elementos que são maléficos à economia como um todo, em sede de cumulatividade tributária, John F. Due (1970, p. 122) expõe seis grandes decréscimos econômicos gerados pela cumulatividade tributária; uma breve análise sobre eles é de grande importância para o estudo em andamento. O primeiro ponto levantado por Due é a verticalização da economia, diminuindo a dinâmica do mercado, fazendo com que as sociedades empresárias concentrem esforços em reduzir trocas econômicas na cadeia produtiva, assumindo quase que o controle total da produção para evitar novas taxações. Outra decorrência apontada é o desequilíbrio econômico entre as empresas, já que as de grande porte são mais aptas a concentrar sua produção, ao passo que as empresas de menor porte e de menor capacidade econômica acabam por reduzir suas participações no mercado, tendendo a falir. O terceiro e quarto efeitos da cumulatividade tributária são recíprocos e dizem respeito às trocas comerciais no mercado global de importação e competitividade interna. A incidência plurifásica tributária diminui a competitividade dos produtos nacionais no mercado externo, diminuindo o volume de exportações, e deixa as empresas nacionais em desequilíbrio com os produtos importados, que, em regra, não sofrem com múltiplas tributações sequenciais. Outra consequência danosa é a dificuldade em se efetivar o princípio da transparência tributária ao consumidor. Por fim, há de se falar no aumento dos custos de fiscalização, já que a impossibilidade de aproveitamento de créditos tributários em função da não-cumulatividade não incentiva a autofiscalização, promovendo o efeito indesejado da evasão e a sonegação fiscal. 
Os enunciados de John F. Due a respeito de delineamentos econômicos dão o tom para justificar o porquê de a não-cumulatividade ser um princípio imperativo de um comando constitucional. O fomento econômico, a dinamicidade da economia, e a proposição de tributação sem acúmulo nos valores devidos ao fisco são as principais razões que fundamentam o princípio em destaque.

Concludentemente há de se observar que o princípio da boa-fé (objetiva) e o princípio da não-cumulatividade são postulados complementares na ordem tributária nacional, de modo que eles se interconectam para ofertar uma proteção ao contribuinte diante das possibilidades de excesso ou de abuso no poder de tributar do Estado. Deve-se reconhecer, bem como o faz o STJ na redação de sua Súmula de $n^{0}$ 509, que a boa-fé, em sua modalidade objetiva, há de servir como elemento comprobatório do escorço fático que leva à conclusão da possibilidade de aproveitamento de créditos de ICMS, caso se comprovem efetivamente as operações de compra e venda que dão azo a tal crédito tributário. Ainda assim, a presente exposição não se encontra completa e acabada, pois há os casos em que a boa-fé é arguida de forma mais genérica e abstrata, inserindo-se na classificação desse princípio como a boa-fé subjetiva. Indaga-se, portanto, a partir de então, se se deve dispensar o mesmo tratamento dado à boa-fé objetiva também à sua modalidade subjetiva. Ao debater tal ponto, far-se-á necessário discorrer na seção posterior sobre a teoria da cegueira deliberada, a qual se aplica adequadamente aos casos de pretensa boa-fé objetiva e à ignorância do agente aos fatos dados.

\section{A TEORIA DA CEGUEIRA DELIBERADA, A BOA-FÉ SUBJETIVA E SUA RELAÇÃO COM DOCUMENTOS IDEOLOGICAMENTE FALSOS}

Na presente seção será apresentada e debatida uma teoria bastante atual que trata, precipuamente, de crimes de lavagem de dinheiro (crimes de colarinho branco) e que, no entanto, será discutida quanto à sua aplicabilidade analógica também para os casos de documentos declarados ideologicamente falsos para fins de aproveitamento de créditos tributários. A nomenclatura dessa teoria é bastante variada e essencialmente plúrima, ela recebe as seguintes denominações: teoria da cegueira deliberada (do original em inglês: willful blindness doctrine), teoria da ignorância deliberada (willful ignorance doctrine), teoria das instruções do avestruz (ostrich instructions doctrine), teoria do ato de ignorância consciente (conscious avoidance doctrine), entre outras terminologias similares porventura utilizadas. Ainda que haja uma pluralidade etimológica, os atos constitutivos que dão 
formalização conceitual a essa doutrina são bastante fáceis de conjecturar, o que será mais bem discutido no desenvolvimento dessa seção.

Inicialmente, será exposta conceitualmente a teoria em tela, para, a partir de então, ser possível traçar um paralelo entre os seus desdobramentos conceituais com a noção de boa-fé subjetiva (já perfunctoriamente mencionada na seção precedente, buscando-se na presente seção concatenar melhor o paralelo sugerido). Por fim, será operada a conexão entre a teoria da cegueira deliberada com a possível utilização de documentos declarados ideologicamente falsos para fins de aproveitamento de créditos tributários, e como ela pode servir também para incidências de multas sem que elas venham a ser consideradas um ato de confisco do ente tributante.

A teoria da cegueira deliberada - no original, willful blindness (nomenclatura que será adotada doravante, após as pormenorizações conceituais devidas nesse parágrafo e em alguns demais que se seguem, em virtude de ter sido a primeira a ser cunhada [EDWARDS, 1954, p. 294] e também por causa de sua maior dispersão e repetição em citações) - possui uma série de outras denominações que acabam por retornar ao seu cerne interpretativo: o não conhecimento (ou ignorância) deliberado de fatos irregulares. Pitorescamente, algumas nomenclaturas fazem menção ao animal avestruz (ostrich instructions doctrine); a alegoria do avestruz faz uma conexão intelectiva com a questão central erigida acerca do quanto uma punição pode ser aplicada com base em uma "ignorância deliberada” (ato de por a cabeça debaixo da terra, comportamento comum aos avestruzes quando se sentem acuados ou com medo, e que não passa de uma forma irracional e pouco efetiva de encarar a realidade), além de uma dúvida razoável. Torna-se despiciendo, portanto, comportar-se de modo indiferente ao que se transcorre ao seu redor, é necessário que o agente feche os olhos para a realidade, seja colocando sua cabeça para debaixo da terra ou de qualquer outra maneira que ele ignore ou se desconecte totalmente dos fatos que lhe são facilmente entendíveis e compreensíveis em sua lida cotidiana.

A pergunta filosófica e juridicamente relevante sobre esse tema diz respeito a se o conhecimento de um fato pode existir na ausência de uma certeza subjetiva ou de uma confirmação objetiva. Essa pergunta passa a ser parcialmente irrelevante (já que a confirmação objetiva de uma regularidade pode ilidir a discussão) quando a ofensa se converte no exato momento em que a ignorância se torna um argumento defensivo do agente. Ou seja, a ignorância deliberada assume a

\footnotetext{
${ }^{4}$ Segundo esse autor, o primeiro registro histórico do termo willful blindness remonta à Inglaterra em 1861, mais especificamente ao caso Regina $v$. Sleep. Essa foi a primeira vez que o termo foi utilizado em um julgamento e a partir de então se popularizou como o mais comum.
} 
feição de uma mens rea (MARTIN, 2015, p. 169) ${ }^{5}$ dotada de caráter ilícito (ROBBINS, 1990, p. 204). Ou seja, o aspecto de ilicitude remanesce no âmago subjetivo do agente e lá mesmo ele é formalizado. Tais aspectos são tidos como necessários para que sua ignorância se ponha como deliberada em desconhecer os fatos, tal como se ele pudesse saber igualmente desses fatos, mas simplesmente opta pelo limbo epistemológico do "não saber", como se tal status fosse garantidor de uma proteção especial contra qualquer imputação de responsabilidade ao agente.

Ao se evitar conscientemente (daí se compreende melhor por que um dos nomes da teoria em inglês é conscious avoidance doctrine) tomar conhecimento de fatos eivados de vícios ou irregularidades já faz depreender uma “omissão” ilícita em tal comportamento, totalmente imbuída de depreciações de ordem moral e ética também. Desse modo, há de se compreender que o desconhecimento deliberado deve ser igualado ao status de mens rea, em todos os pressupostos e derivados de ilicitude que lhe são próprios.

Cumpre-se destacar que o desconhecimento do agente diz respeito aos fatos e não à lei. Ou seja, não se argui o desconhecimento da lei como elemento defensivo, algo que é facilmente contraposto a partir do princípio da publicidade, já que não é válido alegar o descumprimento de uma lei por não conhecê-la - artigo $3^{\circ}$ do Decreto-Lei $n^{\circ}$ 4.657, de 4 de setembro de 1942, mais conhecido como "Lei de Introdução às normas do Direito Brasileiro”-, já que essa é uma posição de defesa muito pobre e diametralmente contra disposição de lei. A cegueira deliberada é muito mais eficaz no plano jurídico porque se atém ao desconhecimento dos fatos e não da lei. Alegar que desconhece a lei já pressupõe saber de algum fato a que a lei pode ou não se aplicar; já, asseverar que desconhece um fato não exige do agente conhecer ou desconhecer a lei (SARCH, 2015, p. 1.084), afinal, nem se sabe qual lei seria aplicável a um fato que é desconhecido. O desconhecimento do fato antecede o conhecimento da lei, daí ser mais plausível e efetivo não conhecer nem sequer os fatos que conduzem a uma aplicação normativa (para fins de defesa argumentativa). Desse modo, a cegueira deliberada versa sempre sobre fatos (alegadamente desconhecidos) e jamais sobre desconhecimento de leis ou atos normativos em geral (constituição, leis complementares, medidas-provisórias, portarias, regulamentos, entre outras espécies normativas).

O propósito primário dessa teoria consiste em prevenir que o indivíduo escape da punição que lhe é devida ao deliberadamente evitar o conhecimento de alguns fatos-chave, fatos de grande relevância para o contexto jurídico em debate (KOZLOV-DAVIS, 2001, p. 478). O intuito primordial em sua concepção se atém a restringir as possibilidades argumentativas de quem almeja se aproveitar

${ }^{5}$ Mens rea é o estado mental que é comumente traduzido como "mente do culpado". Ela consiste no conhecimento subjetivo que a ação ou omissão de outrem pode vir a ser a causa de um cometimento criminoso. 
da própria torpeza (falta de conhecimento sobre fatos que eles poderiam ou deveriam saber) para escapar de punições legais. Para impedir que a mera negativa factual com base no desconhecimento fosse alegada é que a teoria da cegueira deliberada foi erigida.

Sinteticamente, existem dois requisitos básicos estatuídos pela Suprema Corte norteamericana (ESTADOS UNIDOS, 2011) que são utilizados para decidir em prol da configuração da teoria da cegueira deliberada: o primeiro, a crença de que existia uma alta probabilidade que se soubesse dos fatos irregulares; o segundo aponta no sentido de que foram tomadas ações deliberadas no sentido de não tomar conhecimento do fato irregular (O’TOOLE, 2011, p. 2). Nesse compasso, há de se evitar, deliberadamente, confirmar o fato antes que ele possa ser imputado como “conhecimento" ou “estar ciente” por parte do agente; não obstante, usualmente, os fatos postos em discussão são fatos-chave de um contexto fático que contém uma irregularidade e não há, além da simples negação, como o agente os desconhecer (DANIEL, 2013, p. 369). Dessa forma, o agente não precisa dizer desconhecer detalhes sobre fatos que ele poderia saber para que a teoria da cegueira deliberada seja rechaçada, o alto grau de probabilidade de seu conhecimento deve dizer respeito a fatos singulares e de grande monta dentro do contexto da alegação feita. Ademais, não basta um simples desconhecimento passivo dos fatos alegados, é necessária uma inclinação deliberada do agente em desconhecer tais fatos, por mais óbvios e ululantes que eles sejam a quem porventura tenha participado, em maior ou menor grau, do contexto fático discutido.

A teoria da cegueira deliberada, como mencionado previamente no início dessa seção, aplica-se, em regra, a crimes de lavagem de dinheiro (do original em inglês: white-collar crimes), afinal, a jurisprudência norte-americana iniciou a aplicação dessa teoria a esses crimes (ESTADOS UNIDOS, 1976), ainda que, a partir do caso United States v. Jewel, posteriormente, a Suprema Corte dos Estados Unidos já tenha aplicado a outros casos, como o de infringência de patentes. Percebe-se que a jurisprudência norte-americana evoluiu no sentido de aplicar analogicamente essa teoria que surgiu nos meandros do direito penal (criminal) e findou por se espraiar também para o ramo civilista das patentes (e suas quebras, que podem, no direito alienígena em comento, ensejar até mesmo repercussões criminais, embora esse não seja exatamente o caso).

Rapidamente a jurisprudência e o corpo hermenêutico norte-americanos passaram a aplicar, após o caso de Jewel (um crime de colarinho branco em 1976), a teoria da cegueira deliberada também para os casos de tráfico de drogas (MARCUS, 1993, p. 2232). Foi a partir de sua aplicação aos casos de tráfico de entorpecentes que se encorpou o entendimento conceitual de que há um incentivo forte nas quadrilhas criminais para que os indivíduos evitem o conhecimento dos fatos delitivos para que possam evitar uma posterior persecução penal. 
No Brasil, a aplicação da teoria da cegueira deliberada continua bastante relacionada com o direito penal, principalmente em função da sua repercussão após a Ação Penal nº 470, o famoso caso do “mensalão” (BRASIL, 2013). Todavia, já há alguma evolução no sentido de ela ser aplicável também ao processo administrativo (SÃO PAULO, 2014), quando se trata de casos de ação civil pública de improbidade administrativa. Esse excerto excepcional, no entanto, não é capaz de sedimentar um entendimento jurisprudencial (e muito menos acadêmico) no sentido de aplicar a teoria da cegueira deliberada a casos que não sejam de ordem penal, muito menos ao caso tratado de forma principal nesse trabalho, a questão tributária propriamente dita, bem como também ao processo administrativo tributário que trate de aproveitamento de créditos de ICMS que se lastreiam em documentos declarados inidôneos.

Por causa dessa “incipiência” em se aplicar a teoria da cegueira deliberada a outros ramos do direito (que não o direito penal) no sistema judiciário brasileiro se faz necessário argumentar em prol de sua aplicabilidade ao processo administrativo tributário quando o contribuinte almeja aproveitar créditos de ICMS por meio de documentos declarados inidôneos. A respeito do tema central do trabalho em desenvolvimento, há de se indicar que na seção precedente (seção 2) já foi analisada a possibilidade de o contribuinte que age de boa-fé aproveitar os créditos tributários de notas fiscais declaradas inidôneas, desde que seja capaz de demonstrar a veracidade da operação de compra e venda, ou seja, comprovar que o tributo foi recolhido a contento na operação anterior da cadeia produtiva.

Impende destacar que a questão editada na Súmula $n^{\circ} 509$ fecha conceitual e juridicamente a questão quando se trata de uma pormenorização atinente à boa-fé objetiva. Esse detalhamento também já foi bem explanado na seção anterior (seção 2), e não são cabíveis muitas outras elucubrações a esse respeito. Todavia, no que tange à boa-fé subjetiva, é plausível ter que adentrar um pouco mais nesse delineamento específico, já que a mencionada súmula fala apenas em “boa-fé”, sendo imperioso tratar desse princípio em suas duas modalidades, a objetiva (objeto da seção supramencionada) e a subjetiva (que será abordada de agora em diante).

Existe uma linha conceitual muito tênue entre a boa-fé subjetiva (ínsita ao amago da consciência do sujeito) e a má-fé relativizada como desprezo à situação que está em transcurso. Tanto o é que ambas (tanto a má-fé quanto a boa-fé subjetiva) são, em regra, difíceis de serem provadas no âmbito jurisdicional. A aproximação entre boa-fé subjetiva e possíveis atos de má-fé (ou seja, atos imbuídos de ilicitude) se dá de forma mais estreita quando se pensa que a boa-fé subjetiva é mais um conteúdo mental de sinceridade de pensamento que um conceito mais amplo de honestidade, algo que implique atuações nesse sentido (SCHWARTZMAN, 2011, p. 382). Nesse sentido, para fins 
acadêmicos de aprofundamento conceitual, há de se citar, ainda que brevemente, que existe uma perspectiva que tenta fundir as modalidades objetivas e subjetivas da boa-fé, aglutinando-as sob a égide da "honestidade de fato" (HAKES; FRIEDMAN; MARTIN, 2012, p. 1.225). Ainda que pese haver um aprofundado debate sobre o que seria essa "forma híbrida de boa-fé” (BUELL, 2011, p. 622), há de se depreender que para fins jurídicos não há como se trabalhar com modalidades tão indefinidas, ao ponto que a pretensa honestidade de fato (ou no fato) está mais próxima da boa-fé objetiva que do mero diletantismo subjetivista. A grande diferenciação prática entre a má-fé e a boafé subjetiva consiste no entendimento (jurídico) de que a primeira precisa ser obrigatoriamente provada de maneira inarredável ao passo que a segunda, em regra, é presumida.

Na perspectiva da teoria da cegueira deliberada por ora encetada se faz imperioso adotar uma perspectiva mais estreita a respeito da boa-fé (subjetiva), um papel mais comumente encontrado nos países da common law (JERRY II, 1994, p. 1321). Essa é a mesma perspectiva adotada no supracitado verbete da Súmula $\mathrm{n}^{\circ} 509$ do STJ, ainda que de modo inconsciente, que servirá de espeque para a aplicação da teoria da cegueira deliberada a tais casos.

Tomando-se por base que é necessário demonstrar a veracidade das operações de compra e venda que lastreiam o crédito tributário de ICMS ao contribuinte de boa-fé (objetiva), percebe-se, como um consectário lógico, que tal indicação não atinge o contribuinte dotado de mera boa-fé subjetiva. Isso porque o contribuinte nesses casos apenas ignora deliberadamente o fato de que as notas utilizadas para formalizar o crédito tributário são eivadas de vício e não se encontram em plena consonância com as determinações formais do fisco estadual.

Esse é justamente o caso relatado no Acórdão no 21.291/16/2a do Conselho de Contribuintes do Estado de Minas Gerais (já mencionado na introdução do trabalho em tela), pois na decisão em apreço foi aplicada a Súmula $n^{0} 509$ da forma mais hermeneuticamente adequada. Quanto às notas fiscais $n^{0} 281$ e $n^{\circ}$ 602, eram capazes de comprovar inequivocamente a operação de compra e venda entre o fornecedor e o adquirente (aplicação da boa-fé objetiva). Por outro lado, as demais notas foram consideradas inidôneas, e, além disso, foi aplicada a multa isolada prevista no art. 55, inciso XXXI, e a multa de revalidação capitulada no art. 56, inciso II, da Lei n 6.763 (MINAS GERAIS, 1975). Acerca dessa segunda parte, a desconsideração das notas fiscais declaradas inidôneas e que não provaram a operação de compra e venda correspondente ensejou a aplicação da teoria da cegueira deliberada, com a sua consequente punição, qual seja, a aplicação da multa isolada mencionada.

No caso em relevo, a simples existência de notas que foram aceitas em virtude da boa-fé objetiva (ainda que formalmente falsas ideologicamente) não levou à extensão desse mesmo entendimento para as notas fiscais que eram acobertadas meramente pela boa-fé subjetiva (as demais 
notas), já que elas advinham do mesmo fornecedor. Semelhantemente, se uma ignorância deliberada sobre a origem e a constituição válida das notas fiscais (ilicitude e termos mais amplos de tais documentos ficais) não é uma argumentação válida, a assunção da crença na boa-fé (subjetiva) do contribuinte também não o é (EBERHART, 2015, p. 129). Sem embargos, se o agente rejeita o conhecimento e assume o risco ${ }^{6}$ de estar adquirindo produtos com notas fiscais emitidas de forma ilícita, não há qualquer óbice para que lhe sejam aplicadas as punições decorrentes do seu equívoco, e elas serão duas: o não aproveitamento do crédito tributário porventura existente, se as notas tivessem sido emitidas corretamente; e, a aplicação de multa de revalidação e multa isolada.

Resumidamente, como expõe Gabriel de J. Tedesco Wedy (2007, p. 260): “Quando uma informação for prestada ao contribuinte e esta for idônea a fim de criar-lhe confiança, o Fisco tem de agir no sentido desta, a não ser que tenha comunicado de forma clara e expressa ao contribuinte o seu caráter não-vinculativo”. Analisando conjuntamente a citação em apreço e o Acórdão n 21.291, conclui-se que foi justamente o que aconteceu: o Poder Público afastou a incidência total e vinculativa da boa-fé (subjetiva), dada a sua não configuração por notas nem sequer apresentadas. A boa-fé no tocante às notas apresentadas foi respeitada, todavia; o Poder Público informou claramente acerca da não vinculação com as demais notas fiscais não apresentadas, não podendo o efeito da boa-fé ser estendido para elas em virtude de sua compleição defectiva.

Sem embargo, destaque-se que da aplicação da própria multa de revalidação já se decorre, logicamente, a impossibilidade do aproveitamento do crédito. Sua punição se dá em virtude da utilização e da malversação de notas fiscais inidôneas, que não podem ser aproveitadas para seu fim precípuo de aproveitamento de crédito tributário e ainda devem ter seu uso desestimulado por meio de uma punição exemplar. A multa isolada, por seu turno, decorre da tentativa de ludibriar a fiscalização fazendária por um pretenso subterfúgio de boa-fé (subjetiva, transmutado em cegueira deliberada), definido em lei como “prejuízo ao controle fiscal”. Percebe-se que um dos intuitos do princípio da não-cumulatividade (reportado na seção 2) consiste em desestimular a evasão ou sonegação fiscal, de modo que atos contrários a tal premissa devem ser desencorajados mediante sanções legais exemplares, como é o caso da multa isolada. Assim, ela não deve ser compreendida como um “expediente confiscatório”, uma vez que possui lastro legal, teórico e conceitual na teoria da cegueira deliberada para a sua devida aplicação.

\footnotetext{
${ }^{6}$ Mutatis mutandis, tal elemento descritivo é o equivalente ao dolo eventual do direito penal, ainda que o caso concreto verse unicamente sobre direito tributário. Salientando-se, expressamente, que na pesquisa em desenvolvimento não se almeja, em nenhum sentido, debater ou se aprofundar sobre a possível abordagem criminal dos documentos ideologicamente falsos porventura utilizados no processo administrativo tributário.
} 
Nesse passo, há de se buscar dar um fechamento ao tema tratado, enunciando que a boa-fé subjetiva alegada como forma de defesa pelo contribuinte, por vezes, dá-se no intuito de se travestir de cegueira deliberada com o fito de aproveitamento de créditos tributários de ICMS, como o é no caso dado. Desse modo, a aplicação de multas tem o condão de desestimular tal conduta ilícita, com o fito de prover uma justiça eticamente aplicável a tais casos.

\section{CONSIDERAÇÕES FINAIS}

Conclusivamente, há de se asseverar que o aproveitamento de créditos tributários decorrentes de documentos declarados ideologicamente falsos deve obedecer a parâmetros éticos mínimos para que eles sejam validados e aceitos pelo fisco estadual (no caso do ICMS). O verbete contido na Súmula $\mathrm{n}^{\circ} 509$ do STJ é o estandarte jurisdicional que serve de norte para a análise do caso em comento, e, tal verbete, ainda que seja dotado de alguns elementos fundamentais no entendimento de como se dá a sistemática da boa-fé aplicada ao princípio da não-cumulatividade, e, consequentemente, de como deve ser procedido o aproveitamento dos créditos tributários, não é clara ou definitivamente o suficiente para encerrar a análise.

O mencionado verbete é de grande acuidade técnica ao falar da necessidade de demonstração da veracidade (verdade) dos fatos alegados em sede de operações de compra e venda de mercadorias ou bens para fins de aproveitamento creditício do ICMS; no entanto, a mencionada súmula não adentra efetivamente na questão da boa-fé subjetiva, da possibilidade da aplicação da teoria da cegueira determinada e em suas decorrentes sanções (multas). Percorrendo esses temas, e debatendo também os efeitos dos atos declaratórios dos documentos tidos por inidôneos, o trabalho em tela findou por traçar delineamentos teóricos bastante substanciais no sentido de fundamentar a aplicabilidade da teoria da cegueira deliberada (em suas múltiplas variações etimológicas tratadas oportunamente na seção 3) em sede de matéria tributária, uma inovação nessa seara, alargando um pouco sua aplicabilidade, ao menos para o direito brasileiro, haja vista que o direito norte-americano já estendeu consideravelmente sua aplicação noutros ramos jurídicos.

A aplicabilidade analógica da teoria da cegueira deliberada resta, portanto, mais do que aceitável ou plausível, ela se encontra implicitamente posta no mencionado verbete sumulado, e, na prática das decisões dos conselhos de contribuintes ela acaba por ser aplicada, ainda que sem uma menção direta. A aplicação da teoria em relevo satisfaz não apenas um conteúdo jurídico propriamente dito, ela diz respeito ao respeito ético pelos procedimentos e pelas normas técnicas colocadas e validadas pela administração fazendária; sua decorrência mais técnica e mais prática, 
efetivamente, transmuta-se na imposição de penalidades em sede de multa para o contribuinte que se vale de tais expedientes irregulares alegando ou argumentando uma pretensa boa-fé (subjetiva).

Há de se compreender que nem todos os documentos declarados inidôneos, ainda que não tempestivamente arguidos como de boa-fé (objetiva) devem ser, de plano, rechaçados para o fim de aproveitamento de créditos tributários. No entanto, em virtude de um padrão ético mínimo de consideração de tais documentos fiscais (notas), eles devem ser avaliados de acordo com a intencionalidade do contribuinte em não observar a correta formalização do seu crédito, em respeito às operações de compra e venda operadas por seus fornecedores. Nesse aspecto, a teoria da cegueira deliberada é bastante profícua em definir os limites da boa-fé, assentando a aplicabilidade da nãocumulatividade, e também justificando, sem dúvidas, a aplicabilidade de multas com a determinação teleológica de não repetição de um comportamento que atente contra a autofiscalização tributária e seu perfil ético mais abalizado.

\section{REFERÊNCIAS}

AKSELRAD, Moisés. Processo Administrativo Tributário. In: MARTINS, Ives Gandra da Silva (Org.). Caderno de Pesquisas Tributárias: Nova Série n. 5. São Paulo: Revista dos Tribunais, 1999, v. 5, p. 400-429.

ALEXANDRE, Ricardo. Direito Tributário Esquematizado. 5. ed. São Paulo: Método, 2011.

ÁVILA, Humberto Bergmann. Segurança Jurídica: Entre Permanência, Mudança e Realização no Direito Tributário. 4. ed. São Paulo: Malheiros, 2016.

BALEEIRO, Aliomar. Direito Tributário Brasileiro. 10. ed. Rio de Janeiro: Forense, 1991.

BARREIRINHAS, Robinson Sakiyama. Manual de Direito Tributário. 2. ed. São Paulo: Método, 2009.

BORGES, José Souto Maior. Lançamento Tributário. 2. ed. São Paulo: Malheiros, 1999.

BRASIL. Ação Penal no 470/MG. Ação Penal Originária. DJ, 22 de abr. 2013. Diário da Justiça Eletrônico, 23 de abr. 2013.

BRASIL. Constituição da República Federativa do Brasil de 1988. Disponível em: <https://goo.gl/zaRrL>. Acesso em: 15 ago. 2017.

BRASIL. Decreto-Lei no ${ }^{0}$ 4.657, de 4 de setembro de 1942. Lei de Introdução às normas do Direito Brasileiro. Disponível em: <https://goo.gl/bwYMkB>. Acesso em: 18 ago. 2017.

BRASIL. Lei Complementar n. ${ }^{\circ}$ 87, de 13 de setembro de 1996. Dispõe sobre o imposto dos Estados e do Distrito Federal sobre operações relativas à circulação de mercadorias e sobre prestações 
de serviços de transporte interestadual e intermunicipal e de comunicação, e dá outras providências. (Lei Kandir). Disponível em: <https://goo.gl/XRd3uC>. Acesso em: 16 ago. 2017.

BRASIL. Súmula no 509. Superior Tribunal de Justiça. DJ, 23 mar. 2014. Diário da Justiça Eletrônico, 31 mar. 2014.

BUELL, Samuel W. Good Faith and Law Evasion. UCLA Law Review, Los Angeles, v. 58, n. 3, p. 611-666, fev. 2011.

COÊLHO, Sacha Calmon Navarro. Curso de Direito Tributário Brasileiro. 9. ed. Rio de Janeiro: Forense: 2007.

COÊLHO, Sacha Calmon Navarro; LOBATO, Valter. Reflexões sobre o art. da Lei Complementar 118. Segurança Jurídica e a Boa-fé como Valores Constitucionais. As Leis Interpretativas no Direito Tributário Brasileiro. Revista Dialética de Direito Tributário. São Paulo, n. 117, p. 108-123, nov. 2005.

DANIEL, Alex Robert. Willful Blindness: The Hazards of an Evolving Standard of Knowledge. Seton Hall Law Journal, Newark, v. 5, n. 1, p. 347-389, 2013.

DUE, John F. Indirect Taxation in Developing Economies. Baltimore: John Hopkins, 1970.

EBERHART, Sidney C. The Road to Hell was Paved with a Good Faith Belief: Why the Supreme Court Correctly Rejected the Good Faith Belief in the Invalidity of a Patent Defense for Dangerously Narrowing Induced Infringement Liability. Journal of Intellectual Property Law, Athens, v. 23, n. 1, p. 115-142, out. 2015.

EDWARDS, J. The Criminal Degrees of Knowledge. The Modern Law Review, London, v.17, n.1, p. 294-298, 1954.

ESTADOS UNIDOS. Global-Tech Appliances v. SEB S.A., 131 S. Ct. 2060, 2072 (Justice Kennedy, dissenting), 2011.

ESTADOS UNIDOS. United States v. Jewell, 532 F. 2d. 697 9th Cir. (en banc), 1976.

FRUMAROVÁ, Kateřina. Nullity and Other Defects of Administrative Decisions in the Czech Republic. Baltic Journal of European Studies, Tallinn, v. 5, n. 2, p. 70-89, out. 2015.

HAKES, Russell A.; FRIEDMAN, Stephen E.; MARTIN, Jennifer S. Uniform Commercial Code Survey: Introduction. The Business Lawyer, Chicago, v. 67, n. 4, p. 1.225-1.226, Aug. 2012.

JERRY II, Robert H. The Wrong Side of the Mountain: A Comment on Bad Faith's Unnatural History. Texas Law Review, Austin, v. 72, n. 2, p. 1317-1331, Mar. 1994.

KOZLOV-DAVIS, Jessica A. A Hybrid Approach to the Use of Deliberate Ignorance in Conspiracy Cases. Michigan Law Review, Ann Arbor, v. 100, n. 2, p. 473-483, Jun. 2001.

LUENGO, Javier García. El Principio de Protección de la Confianza en el Derecho Administrativo. Madrid: Civitas, 2002. 
MARCUS, Jonathan L. Note: Model Penal Code Section 2.02(7) and Willful Blindness. Yale Law Journal, New Haven, v. 102 n. 8, p. 2.231-2.234, Jun. 1993.

MARQUES, Cláudia Lima. Contratos no Código de Defesa do Consumidor: O Novo Regime das Relações Contratuais. 4. ed. São Paulo: Revista dos Tribunais, 2004.

MARQUES, Cláudia Lima. Direitos Básicos do Consumidor na Sociedade Pós-Moderna de Serviços: O Aparecimento de um Sujeito Novo e a Realização de Novos Direitos. Revista de Direito do Consumidor, São Paulo, v. 35, n. 3, jul./set. 2000.

MARTIN, Elizabeth A. Oxford Dictionary of Law. 8. ed. Oxford: Oxford UP, 2015.

MELO, José Eduardo Soares de; LIPPO, Luiz Francisco. A Não-Cumulatividade Tributária (ICMS, IPI, ISS, PIS e Cofins). 3. ed. São Paulo: Dialética, 2008.

MINAS GERAIS. Decreto $\mathbf{n}^{\circ} 43.080$ de 13 de dezembro 2002. Regulamento do Imposto Sobre Operações Relativas à Circulação de Mercadorias e Sobre Prestações de Serviços de Transporte Interestadual e Intermunicipal e de Comunicação. Disponível em: <https://goo.gl/oz3oVL>. Acesso às 11:00h do dia 16 de agosto de 2017.

MINAS GERAIS. Lei nº 6.763, de 26 de dezembro de 1975. Consolidação da Legislação Tributária do Estado de Minas Gerais. Disponível em: <https:/goo.gl/gSL6Wm>. Acesso em: 15 ago. 2017.

O’TOOLE, Timothy P. Patently Unusual: How a Recent Supreme Court Patent Decision Alters the Landscape for Proving Criminal Knowledge. Westlaw Journal Intellectual Property, Eagan, v. 18 n. 10, p. 1-3, fev. 2011.

RIBEIRO, Joaquim de Souza. O Controlo do Conteúdo dos Contratos: Uma Nova Dimensão da Boafé. Revista da Faculdade de Direito UFPR, Curitiba, v. 42, n. 1, p. 5-34, 2005. Disponível em: $<$ https://goo.gl/ynJPw5>. Acesso em: 23 out. 2018.

ROBBINS, Ira P. The Ostrich Instruction: Deliberate Ignorance as a Criminal Mens Rea. Journal of Criminal Law \& Criminology, Chicago, v. 81, n. 2, p. 191-234, Jun. 1990.

ROSA, José Roberto; PARRI, Heloisa Helena. ICMS na Prática. 2. ed. São Paulo: Meta, 1995.

SÃO PAULO (ESTADO). 0009252-56.2010.8.26.0073. Apelação Cível. DJ, 09 abr. de 2014. 9a Câmara de Direito Público, Diário da Justiça Eletrônico, 10 de abr. 2014.

SARCH, Alexander F. Willful Ignorance, Culpability, and the Criminal Law. St. John's Law Review, New York, v. 88, n. 4, p. 1.023-1.112, Dec. 2015.

SCHNORR, Randolf. Die Gemeinschaft nach Bruchteilen (§§ 741 - 758 BGB). Tübingen: Mohr Siebeck, 2004.

SCHWARTZMAN, Micah. The Sincerity of Public Reason. Journal of Political Philosophy, Hoboken, v. 19, n. 4, p. 375-392, Dec. 2011. 
TARSKI, Alfred. Verdade e Demonstração. In: TARSKI, Alfred. A Concepção Semântica da Verdade. Tradução Celso Braida et al. São Paulo: Unesp, 2007, p. 203-233.

TORRES, Ricardo Lobo. Curso de Direito Financeiro. 20. ed. Rio de Janeiro: Renovar, 2018.

VAN DER BRUGGEN, Edwin. Good Faith in the Application and Interpretation of Double Taxation Conventions. British Tax Review, London, v. 120, n. 1, p. 25-59, Feb. 2003.

VENOSA, Sílvio de Salvo. Direito Civil: Teoria Geral das Obrigações e Teoria Geral dos Contratos. 14. ed. São Paulo: Atlas, 2014.

VICENTE, Petrúcio Malafaia. Crédito Tributário. In: GOMES, Marcus Lívio; ANTONELLI, Leonardo Pietro. Curso de Direito Tributário Brasileiro. São Paulo: Quartier Latin, 2016, v. 1, p. 241-289.

VIEGAS, Vera Lúcia. Ius Cogens e o Tema da Nulidade dos Tratados. Revista de Informação Legislativa, Brasília, v. 36, n. 1, p. 181-196, out. 1999.

WEDY, Gabriel de J. Tedesco. O princípio da Boa-Fé Objetiva no Direito Tributário. Porto Alegre, Revista da AJUFERGS, v. 3, n. 1, p. 251-287, maio/jun., 2007.

WICHARY, Stefan. Diskussionsbericht zu §§ 5 und 6. In: KLÖHN, Lars; RIESENHUBER, Karl (Orgs.). Urhebervertragsrecht im Lichte der Verhaltensökonomik. Berlin: De Gruyter, 2010.

WIELING, Hans Josef. Sachenrecht: Sachen, Besitz und Rechte an beweglichen Sachen. V. 1. Berlin: Springer, 2006.

Bacharel, Mestre e Doutor em Filosofia e Bacharel em Direito pela Universidade Federal do Rio Grande do Norte. Especialista em Direito e Processo do Trabalho pela Universidade Cândido Mendes - RJ. Oficial de Justiça Avaliador Federal no TRT 21. E-mail: lauroericksen@yahoo.com.br 